Available online at: http://ejournal-balitbang.kkp.go.id/index.php/iaj

\title{
INFLUENCE OF SQUID LIVER MEAL IN MATURATION DIET ON GONADOSOMATIC INDEX AND GONADAL AMINO ACID CONTENT OF GOLDEN SPOTTED RABBITFISH, Siganus guttatus
}

\author{
Asda Laining", Ike Trismawanti, Usman, and Muhammad Hafid Masruri \\ Research Institute for Coastal Aquaculture \\ Jl. Makmur Dg. Sitakka No. 129, Maros 90512, South Sulawesi, Indonesia
}

(Received 16 March 2018; Final revised 9 January 2019; Accepted 9 January 2019)

\begin{abstract}
A four months feeding trial was conducted to evaluate the effects of two maturation diets containing either fishmeal (FM) or squid liver meal (SLM) as the major protein source on growth, gonadosomatic index and gonadal bio-chemical profiles of golden spotted rabbitfish, Siganus guttatus. The two tested diets were formulated to be iso-nitrogenous $(40 \%)$ and iso-lipidic $(14 \%)$ and supplemented with several micronutrients specifically for gonadal development. The initial weight of golden spotted rabbitfish used were $352.6 \pm$ $45.0 \mathrm{~g}$ and stocked into four of $2 \mathrm{~m} \times 2 \mathrm{~m} \times 2.5 \mathrm{~m}$ net cages with 25 fish per cage. The test diets were fed to the stocks twice a day. After four months feeding, the weight gains (WG) of broodstock fed the two diets were nearly similar in which FM had WG of $40.1 \pm 2.2 \%$ and $42.8 \pm 2.0 \%$ for SLM. The GSI of male fed SLM diet was similar to that of fed with FM. However, the GSI of female fed FM was $5.6 \pm 0.1 \%$ significantly lower $(\mathrm{P}<0.05)$ than SLM which was $11.4 \pm 0.5 \%$ Furthermore, total amino acid (TAA) in spermatocyte was significantly $(P<0.05)$ influenced by dietary SLM indicated by its higher TAA $(62.4 \%$ compared to TAA content of FM group $(46.1 \%$. Similarly, the TAA content in oocyte was significantly $(P<0.05)$ improved when fed SLM. The dietary SLM did not affect the TAA content in the fillet of rabbitfish demonstrated by the similarity of the fillet TAA content in the two groups which was 55.6\%for FM and 54.1\%for SLM. Dietary SLM enhanced GSI of female broodstocks and profile of amino acid in the gonad of golden spotted rabbitfish, Siganus guttatus.
\end{abstract}

\section{KEYWORDS: squid liver meal; maturation diet; gonadal amino acid content; gonadosomatic} index; rabbitfish

\section{INTRODUCTION}

Golden spotted rabbitfish, Siganus guttatus is considered to be a promising candidate for marine aquaculture development by virtue of its herbivorous/omnivorous feeding habits and consequent ability to feed low on the aquatic food chain (Duray, 1998; Tacon et al., 1990). In nature, rabbitfish feed on algae, seaweed, and other aquatic plants (Parazo, 1990; Bariche, 2006; Jaikumar, 2012) and in captivity can readily to accept artificial feeds, making them feasible to be grown on commercial scale (Tacon et al., 1990; Laining et al., 2017a).

\footnotetext{
\# Correspondence: Research Institute for Coastal Aquaculture and Fisheries Extension. Jl. Makmur Dg. Sitakka No. 129, Maros 90512, South Sulawesi, Indonesia Phone: + 62411371544

E-mail: asdalaining@yahoo.com
}

Although rabbitfish has several attributes to support their suitability for aquaculture (Saoud et al., 2008), seed production of the species has not been successful so far (Avila \& Juario, 1987; Rachmansyah et al., 2007). In addition, commercial diet for maturation stage of rabbitfish so far has not been available in Indonesia (Laining et al., 2015). Therefore, it is necessary to develop a broodstock diet to produce good quality of the seed.

Reproductive performances of fish depend principally on broodstock nutrition (Callan et al., 2012). Function of various components for broodstock diets such as protein (Tandler et al., 1995), essential fatty acid (Coman et al., 2011), vitamin E dan C (Binh et al., 2012; Koshio, 2010), and carotenoid (VasalloAgius et al., 2002; Laining et al., 2017b) have been intensively studied for several species. The role of protein and the requirement of specific amino acids 
for the production of good-quality eggs have been better established in marine species (Moran et al., 2007). Moreover, diet with balanced essential amino acids improved vitellogenin synthesis in gilthead seabream (Tandler et al., 1995) while a low protein and high calorie diet caused a reduction reproductive performance in red sea bream (Watanabe $\&$ Kiron, 1995) and seabass (Cerda et al., 1994).

Utilization of certain feed ingredients has been reported to improve the quality of fish eggs. For instances, squid meal increases the eggs quality of red seabream, Pagrus major (Watanabe et al., 1991), gilthead sea bream, S. aurata (Fernandez-Palacios et al., 1997) and striped jack (Vassallo-Agius et al., 2001) probably due to its good protein quality and high content of phospholipid and cholesterol (Watanabe et al., 1991; Hertrampf \& Piedad-Pascual, 2000). In the market, the are two types of squid meals which are premium squid meal and squid liver meal (SLM). Premium squid meal is made only from the muscle of the squid while SLM is produced from whole body of the squid including gut content (viscera). In order to determine the influence of squid liver meal (SLM) on growth, gonadosomatic index (GSI) and bio-chemical profiles of oocyte and spermatocyte, two experimental diets were fed to matured golden spotted rabbitfish (Siganus guttatus).

\section{MATERIALS AND METHODS}

\section{Squid Liver Meal And Experimental Maturation Diets}

Several protein sources were utilized to formulate the two maturation diets with fish meal and squid liver meal as the tested ingredients (Table 1). All these protein sources were locally purchased excluding the Korean SLM. Among the protein sources, fish meal contained the highest protein content of approximately $65 \%$ The SLM used in this experiment contains protein content approximately $43 \%$ As the car- bohydrate sources, wheat four was included in the two maturation diets at the same level of $8 \%$ while sorghum was only added in one diet to adjust its protein level.

The experiment consisted of two maturation diets containing either fish meal (FM) or squid liver meal (SLM) as the major protein source at the level of $45 \%$ respectively. Each of the diet was still formulated to contain either fish meal or SLM at the minimum level of $5 \%$ The two tested diets were formulated to be iso-nitrogenous $(40 \%)$ and iso-lipidic ( $14 \%)$ and supplemented with several micro-nutrients specifically for gonadal development including vitamin $C$, vitamin $E$, and carotenoid mixture (Table 2 ). In order to meet the required protein level of SLM diet, it was also incorporated with mysid meal at level of $20 \%$ All dry ingredients were mixed thoroughly and oil containing lipid solubled-vitamins and carotenoid was added and then mixed again for 30 minutes. Further, water was added at level of $350-400 \mathrm{~g} / \mathrm{kg}$ of the dry ingredients (Laining et al., 2017a). The mixture was then passed through a pelletizer (Hiraga, Co. Ltd, Kobe, Japan) and dried in oven. All test diets were stored in air-tight polyethylene bags in a freezer ($20^{\circ} \mathrm{C}$ ) until used.

Initial weight of wild golden spotted rabbitfish used were $352.6 \pm 45.0 \mathrm{~g}$ and stocked into four of 2 $\mathrm{m} \times 2 \mathrm{~m} \times 2.5 \mathrm{~m}$ net cages with 25 fish per cage. The test diets were fed to the broodstocks twice a day in the morning at 08:00 and in the afternoon at 16:00. The feeding trial lasted for four months.

\section{Sample Collection, Bio-Chemical Analysis, and Statistic}

At the end of the feeding trial, three maturing fishes for both male and female were collected from each cages and sacrificed for measuring the GSI and HSI. After weighing, the gonad samples (oocytes and spermatocytes) were freeze-dried and kept at $-20^{\circ} \mathrm{C}$

Table 1. Proximate composition (\%dry basis) of feed ingredients used as protein and carbohydrate sources for the experimental maturation diets

\begin{tabular}{lccccc}
\hline \multicolumn{1}{c}{ Ingredients } & Crude protein & Lipid & Ash & Fibre & NFE \\
\hline Fish meal & 65.0 & 7.4 & 20.8 & 1.2 & 5.6 \\
Mysid meal & 53.0 & 4.0 & NA* & 2.7 & - \\
Soybean meal & 40.5 & 17.5 & 5.8 & 8.6 & 27.6 \\
Squid liver meal & 43.0 & 10.9 & 10.5 & 12.3 & 23.3 \\
Wheat flour & 12.0 & 0.3 & 6.2 & 4.6 & 76.9 \\
Sorghum & 8.4 & 5.0 & 2.7 & 2.7 & 81.2 \\
\hline
\end{tabular}

Note: *NA: not analyzed 
Table 2. Formulation and proximates composition of experimental maturation diets

\begin{tabular}{lcc}
\hline & \multicolumn{2}{c}{ Experimental maturation } \\
\cline { 2 - 3 } & Ingredients (\%) & FLM \\
\hline Fish meal & 45 & 5 \\
Mysid meal & 5 & 20 \\
Soybean meal & 5 & 5 \\
Squid liver meal & 5 & 45 \\
Wheat flour & 8 & 8 \\
Sorghum & 13 & 0 \\
Fish oil & 5 & 3 \\
Olive oil & 3 & 3 \\
Vitamin mix & 3 & 3 \\
Mineral mix & 3 & 3 \\
Organic mineral & 1 & 1 \\
Carotenoid mixture* & 0.77 & 0.77 \\
Lecithin & 0.2 & 0.2 \\
Aquasterol & 0.5 & 0.5 \\
Stay-C & 0.1 & 0.1 \\
Vitamin E & 0.04 & 0.04 \\
CMC & 2.39 & 2.39 \\
\hline Proximate composition (\% dry basis) & & \\
Lipid & 14.0 & 14.4 \\
Crude protein & 40.2 & 40.9 \\
Fiber & 3.7 & 3.7 \\
Ash & $*$ NA & NA \\
\hline Note: * Astaxanthin source $0.2 \%$ cantaxanthine source $0.07 \%$ and Spirulina powder \\
$\quad$ 0.5\% * NA: not analyzed & & \\
& &
\end{tabular}

until analysis. Dissected fish were then filleted to take the muscle, oven-dried and kept at $-20^{\circ} \mathrm{C}$ until chemical analysis. Bio-chemical analysis for samples (feed, oocyte, spermatocyte, and muscle) were performed for proximate analysis according to AOAC International (2005). Briefly, moisture was analyzed after drying the samples at $105^{\circ} \mathrm{C}$ for 16 hours using an oven (Memmert, Germany). Ash was analyzed using a muffle furnace at $550^{\circ} \mathrm{C}$ (Barnstead, Thermolyne, CA, USA). Crude protein was determined according to microKjeldahl procedure (digestion, distillation, and titration). Lipid was extracted using chloroform and methanol. Furthermore, analysis of total amino acid was performed with HPLC (Shimadzu 20A, Tokyo, Japan).

Variables observed were weight gain (WG), gonadosomatic index (GSI), hepatosomatic index (HSI), and amino acid profiles of gonads and fillet of both male and female broodstocks. GSI (\%) was calculated as GSI $=100 \times$ (weight of gonad/body weight) and $\mathrm{HSI}(\%$ was calculated as $\mathrm{HSI}=100 \times$ (weight of liver/body weight). All data obtained were statiscally analyzed using Independent t-test with software SPSS (version 21; SPSS, Inc., Chicago, Illinois, USA). Differences were considered significant at $\mathrm{P}<0.05$.

\section{RESULTS AND DISCUSSION}

After four months feeding, the weight gains (WG) of broodstock fed the two diets were nearly similar in which FM had WG of $40.1 \pm 2.2 \%$ and $42.8 \pm 2.0 \%$ for SLM. The growth of fish from the two groups increased slowly during the four months culture as illustrated by Figure 1. The slow growth of the fish in both groups indicated that the fish were in the maturation stage or the fish has been categorized as a broodstock.

Growth response observed in the present study implied that SLM has no benefit on gowth when fish are given at maturation stage. Unlikely when fish fed during the growth phase, a positive correlation was found between the growth performance of juvenile Japanese seabass (Lateolabrax japonicus) and the supple- 


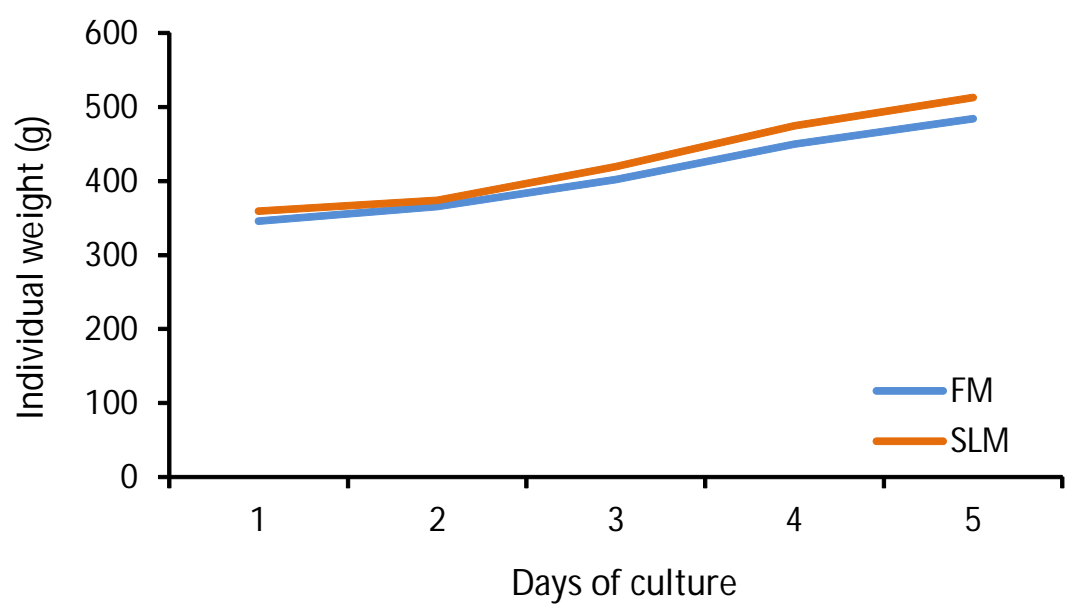

Figure 1. Pattern of weight increment of golden spotted rabbitfish S. guttatus fed two maturation diets.

mentation of squid viscera meal (SVM), indicating that SVM can stimulate juvenile to grow (Mai et al., 2006). Liang et al. (2000) also reported that SVM supplementation increased the growth of three marine species Chrysophrys major, Fugu rubripes and Moroul satatilis. Kader et al. (2012) revealed that fermented soybean meal combined with squid by-product blend stimulated the growth, feed utilization, and health of Japanese flounder, Paralichthys olivaceus. The very slow growth of the rabbitfish fed the two diets found in the present study might be the result of a genetic predisposition (maximum size achieved for older fish) (Mejri et al., 2017). For instances, tiger shrimp at age of 11 months grew faster ( $170 \%$ of WG) than those with age of 16 months ( $30 \%$ of WG) (Laining et al., 2017b).

Table 3 presents the GSI of male fed SLM diet was similar to that of fed with FM which was $7.5 \pm 0.2 \%$ and $8.1 \pm 0.3 \%$ respectively. The GSI of female fed FM diet was $5.6 \pm 0.1 \%$ significantly lower than GSI of female fed SLM which was $11.4 \pm 0.5 \%$ The significant effect of SLM on GSI of female may imply the effect of SLM on fecundity which was not measured in the present study. Recent studies evaluating the SLM or other types of squid meal on reproductive performances are not readily available, and therefore difficult to compare with findings of the present study. However, Fernandez-Palacios et al. (1997) revealed that fat-insoluble fraction of squid meal improved the egg quality of gilthead sea bream (Sparus aurata) broodstock in regard to fecundity produced per kilogram of female and percentages of viable and fertilized eggs. Even though, the SLM significantly enhanced the GSI of female spawners, no significant effect $(P>0.05)$ was observed on $\mathrm{GSI}$ of male broodstocks.
Proximate composition of oocyte and spermatocyte are presented in Table 4. No differences were found on the macro-nutrient content of oocyte for both goups of fish fed FM and SLM diets. In term of spermatocyte, the crude protein, and lipid content were similar for both goups of fish fed SLM and FM. However, ash content was slightly increased in fish fed SLM. Furthermore, crude protein content of spermatocyte was higher than in oocyte while the lipid content was lower in spermatocyte than in oocyte. These may indicated that lipid is more necessary for oocyte than in spermatocyte. Nutrient in eggs depend primarily on broodstock nutrition (Callan et al., 2012), while the approppriate biochemical composition in eggs is necessary to meet the development requirements of embryonic and larval stages (Araujo et al., 2012). The high protein content in both 00 cyte and spermatocyte suggested that protein is highly required for gonadal development of rabbitfish. Protein is the most abundant component of the nutrients contained in the egg of many of the fish species studied (Watanabe \& Vasallo-Agius, 2003).

Furthermore, total amino acid (TAA) in spermatocyte was positively influenced by dietary SLM indicated by its higher TAA $(62.4 \%$ compared to TAA content of FM group $(46.1 \%$ as presented by Table 5 . The same pattern was also observed in oocyte where the TAA content in oocyte was improved when fish fed SLM rather than FM diet $(49.3 \%$ vs $30.1 \%$ respectively). The significant higher TAA both in oocyte and spermatocyte of fish fed SLM than those fed with FM diet indicated that protein of SLM may be more available and more benefit for gonadal development of rabbitfish compared to fish meal. The dominant amino acid in spermatocyte of rabbitfish found in SLM whose content was more than $5 \%$ of TAA were as- 
Table 3. GSI (\%) and HSI (\%) of female and male stocks of golden spotted rabbitfish fed two maturation diets

\begin{tabular}{lcccccc}
\hline \multirow{2}{*}{ Diets } & \multicolumn{2}{c}{ Female } & & \multicolumn{2}{c}{ Male } \\
\cline { 2 - 3 } \cline { 5 - 6 } & GSI & HSI & & GSI & HSI \\
\hline FM & $5.6 \pm 0.1^{\mathrm{a}}$ & $2.0 \pm 0.0^{\mathrm{a}}$ & & $7.5 \pm 0.2^{\mathrm{a}}$ & $1.5 \pm 0.0^{\mathrm{a}}$ \\
SLM & $11.4 \pm 0.5^{\mathrm{b}}$ & $3.5 \pm 0.2^{\mathrm{b}}$ & & $8.1 \pm 0.3^{\mathrm{a}}$ & $1.7 \pm 0.0^{\mathrm{a}}$ \\
\hline
\end{tabular}

Description: All values are mean $\pm \mathrm{SD}$. Different superscript letters within each group indicate significant different mean $(P<0.05)$

Table 4. Proximate composition (\%dry basis) of oocyte and spermatocyte of golden spotted rabbitfish fed two maturation diets

\begin{tabular}{lccccc}
\hline \multirow{2}{*}{ Nutrients } & \multicolumn{2}{c}{ Oocyte } & & \multicolumn{2}{c}{ Spermatocyte } \\
\cline { 2 - 3 } \cline { 5 - 6 } & FM & SLM & & FM & SLM \\
\hline Lipid & $8.4 \pm 0.1^{\mathrm{a}}$ & $8.6 \pm 0.4^{\mathrm{a}}$ & & $2.6 \pm 0.4^{\mathrm{a}}$ & $3.1 \pm 0.3^{\mathrm{a}}$ \\
Crude protein & $68.5 \pm 0.6^{\mathrm{a}}$ & $68.5 \pm 0.7^{\mathrm{a}}$ & & $72.7 \pm 2.3^{\mathrm{a}}$ & $76.7 \pm 0.6^{\mathrm{a}}$ \\
Ash & $12.8 \pm 1.4^{\mathrm{a}}$ & $10.9 \pm 0.1^{\mathrm{a}}$ & & $11.6 \pm 0.4^{\mathrm{a}}$ & $14.2 \pm 0.5^{\mathrm{b}}$ \\
\hline
\end{tabular}

Description: All values are mean \pm SD. Different superscript letters within each group indicate significant different mean $(P<0.05)$

partic acid, glutamic acid, glycine, arginine, and leucine. In oocyte, the dominant amino acid content (> $5 \%$ was only glutamic acid and other amino acids including aspartic acid, arginine, alanine, valine, isoleucine, leucine, and lysine had moderate level between $3 \% 5 \%$ of TAA. According to Mejri et al. (2017) amino acid leucine, lysine, valine, isoleucine, alanine, aspartic acid, serine, and glutamic acid were important in eggs and larvae of walleye (Sander vitreus), with the highest values reported for lysine and leucine in essential amino acid fraction. In gilthead seabream egg, amino acid composition of vitelline envelope proteins is characterized by a high content of proline and glutamic acid and relatively low content of cysteine (Hyllner et al., 1995).

The dietary SLM did not significantly $(P>0.05)$ affect the TAA content in the fillet of golden spotted rabbitfish when fed at maturation stage demonstrated by the similarity of the fillet TAA content in the two groups of fish which was $55.6 \%$ for FM and $54.1 \%$ for SLM (Table 6). The individual amino acid in fillet was also not influenced by dietary SLM. These pattern was different from amino acid profile in gonads in which dietary SLM significantly improved most of their amino acid contents.

Table 7 presents the proximate composition of liver after four months feeding trial. There was no clear effect of the dietary treatments on the nutrient content in the liver. The protein content was approximately $45 \%$ in both groups of fish fed FM and SLM diet, respectively. The liver lipid content was relatively low which was $4.1 \%$ for FM and $2.0 \%$ for SLM.

Based on GSI values and amino acid content in both oocytes and spermatocytes, reproductive performance of golden spotted rabbitfish could be improved by using LSM as the major dietary protein source. Concentration of TAA in spermatocytes of fish fed LSM diet increased approximately 35\% and the improvement was more pronounced observed in oocytes which its TAA increased $63.8 \%$ compared to fish fed FM diet. According to Penaflorida (1989), amino acid profile of squid meal is well balanced with index is high (0.96) similar to white fish meal (0.96) and shrimp meal (0.98). Besides its balanced amino acid profile, rabbitfish may have ability to absorb nutrient in SLM more efficiently than FM. Although determination of nutrient digestibility coefficient of SLM was not carried-out for this present experiment, squid meal has high protein, and dry matter digestibility for tiger prawn which is $96.0 \%$ and $85.5 \%$ repectively (Hertrampf \& Piedad-Pascual, 2000). This indicates that tiger shrimp can efficiently utilise dietary LSM. However, the positive effects of dietary LSM on amino acid content was not observed in fil- 
Table 5. Amino acid profile (\% dry matter) of oocyte and spermatocyte of golden spotted rabbitfish fed two maturation diets

\begin{tabular}{lccccc}
\hline \multirow{2}{*}{ Amino acid } & \multicolumn{2}{c}{ Spermatocyte } & & \multicolumn{2}{c}{ Oocyte } \\
\cline { 2 - 3 } \cline { 5 - 6 } & FM & SLM & FM & SLM \\
\hline Aspartic acid & $3.87 \pm 0.06^{\mathrm{a}}$ & $5.49 \pm 0.12^{\mathrm{b}}$ & & $3.30 \pm 0.14^{\mathrm{a}}$ & $4.55 \pm 0.08^{\mathrm{b}}$ \\
Glutamic acid & $7.43 \pm 0.03^{\mathrm{a}}$ & $9.81 \pm 0.04^{\mathrm{b}}$ & & $5.01 \pm 0.01^{\mathrm{a}}$ & $6.96 \pm 0.07^{\mathrm{b}}$ \\
Serine & $1.84 \pm 0.08^{\mathrm{a}}$ & $2.29 \pm 0.08^{\mathrm{b}}$ & & $1.12 \pm 0.15^{\mathrm{a}}$ & $2.91 \pm 0.03^{\mathrm{b}}$ \\
Histidine & $1.10 \pm 0.17^{\mathrm{a}}$ & $1.32 \pm 0.06^{\mathrm{a}}$ & & $0.84 \pm 0.04^{\mathrm{a}}$ & $1.32 \pm 0.01^{\mathrm{b}}$ \\
Glycine & $3.78 \pm 0.08^{\mathrm{a}}$ & $5.12 \pm 0.03^{\mathrm{b}}$ & & $3.02 \pm 0.05^{\mathrm{a}}$ & $2.14 \pm 0.02^{\mathrm{b}}$ \\
Threonine & $2.20 \pm 0.29^{\mathrm{a}}$ & $2.88 \pm 0.15^{\mathrm{a}}$ & & $1.53 \pm 0.02^{\mathrm{a}}$ & $2.59 \pm 0.01^{\mathrm{b}}$ \\
Arginine & $5.42 \pm 0.14^{\mathrm{a}}$ & $8.53 \pm 0.01^{\mathrm{b}}$ & & $2.49 \pm 0.05^{\mathrm{a}}$ & $3.84 \pm 0.02^{\mathrm{b}}$ \\
Alanine & $3.50 \pm 0.03^{\mathrm{a}}$ & $4.02 \pm 0.06^{\mathrm{b}}$ & & $1.73 \pm 0.02^{\mathrm{a}}$ & $3.53 \pm 0.08^{\mathrm{b}}$ \\
Tyrosine & $1.61 \pm 0.06^{\mathrm{a}}$ & $2.18 \pm 0.02^{\mathrm{b}}$ & & $0.28 \pm 0.03^{\mathrm{a}}$ & $2.16 \pm 0.03^{\mathrm{b}}$ \\
Methionine & $1.12 \pm 0.02^{\mathrm{a}}$ & $1.45 \pm 0.06^{\mathrm{b}}$ & & $0.88 \pm 0.03^{\mathrm{a}}$ & $1.10 \pm 0.02^{\mathrm{b}}$ \\
Valine & $2.84 \pm 0.07^{\mathrm{a}}$ & $3.71 \pm 0.14^{\mathrm{b}}$ & & $1.88 \pm 0.03^{\mathrm{a}}$ & $3.60 \pm 0.02^{\mathrm{b}}$ \\
Phenylalanine & $1.89 \pm 0.06^{\mathrm{a}}$ & $2.48 \pm 0.08^{\mathrm{b}}$ & & $1.55 \pm 0.03^{\mathrm{a}}$ & $2.68 \pm 0.02^{\mathrm{b}}$ \\
Isoleucine & $2.20 \pm 0.23^{\mathrm{a}}$ & $2.89 \pm 0.11^{\mathrm{a}}$ & & $1.70 \pm 0.06^{\mathrm{a}}$ & $3.20 \pm 0.03^{\mathrm{b}}$ \\
Leucine & $4.12 \pm 0.09^{\mathrm{a}}$ & $5.61 \pm 0.14^{\mathrm{b}}$ & & $2.46 \pm 0.01^{\mathrm{a}}$ & $4.74 \pm 0.02^{\mathrm{b}}$ \\
Lysine & $3.16 \pm 0.05^{\mathrm{a}}$ & $4.60 \pm 0.14^{\mathrm{b}}$ & & $2.31 \pm 0.03^{\mathrm{a}}$ & $3.99 \pm 0.16^{\mathrm{b}}$ \\
\hline \multicolumn{1}{c}{ Total } & $46.09 \pm 1.19^{\mathrm{a}}$ & $62.4 \pm 0.11^{\mathrm{b}}$ & & $30.1 \pm 0.18^{\mathrm{a}}$ & $49.31 \pm 0.08^{\mathrm{b}}$ \\
\hline
\end{tabular}

Description: All values are mean \pm SD. Different superscript letters across columns within each group indicate significant different mean $(P<0.05)$

Table 6. Amino acid profile (\% dry matter \pm SD) of female stock fillet of golden spotted rabbitfish fed two maturation diets

\begin{tabular}{lcc}
\hline \multicolumn{1}{c}{ Parameter } & Fillet FM & Fillet SLM \\
\hline Aspartic acid & $5.58 \pm 0.08^{\mathrm{a}}$ & $5.91 \pm 0.14^{\mathrm{a}}$ \\
Glutamic acid & $8.64 \pm 0.03^{\mathrm{a}}$ & $9.38 \pm 0.23^{\mathrm{a}}$ \\
Serine & $2.25 \pm 0.09^{\mathrm{a}}$ & $2.40 \pm 0.16^{\mathrm{a}}$ \\
Histidine & $5.91 \pm 0.06^{\mathrm{a}}$ & $1.29 \pm 0.04^{\mathrm{a}}$ \\
Glycine & $2.99 \pm 0.18^{\mathrm{a}}$ & $3.16 \pm 0.13^{\mathrm{a}}$ \\
Threonine & $2.73 \pm 0.03^{\mathrm{a}}$ & $2.87 \pm 0.18^{\mathrm{a}}$ \\
Arginine & $3.61 \pm 0.04^{\mathrm{a}}$ & $3.84 \pm 0.11^{\mathrm{a}}$ \\
Alanine & $3.44 \pm 0.03^{\mathrm{a}}$ & $3.66 \pm 0.28^{\mathrm{a}}$ \\
Tyrosine & $1.87 \pm 0.16^{\mathrm{a}}$ & $1.94 \pm 0.06^{\mathrm{a}}$ \\
Methionine & $1.57 \pm 0.17^{\mathrm{a}}$ & $1.74 \pm 0.06^{\mathrm{a}}$ \\
Valine & $2.91 \pm 0.27^{\mathrm{a}}$ & $3.08 \pm 0.20^{\mathrm{a}}$ \\
Phenylalanine & $2.26 \pm 0.09^{\mathrm{a}}$ & $2.40 \pm 0.71^{\mathrm{a}}$ \\
I-leucine & $2.71 \pm 0.05^{\mathrm{a}}$ & $2.85 \pm 0.35^{\mathrm{a}}$ \\
Leucine & $4.33 \pm 0.13^{\mathrm{a}}$ & $4.64 \pm 0.42^{\mathrm{a}}$ \\
Lysine & $4.74 \pm 0.08^{\mathrm{a}}$ & $4.96 \pm 0.21^{\mathrm{a}}$ \\
Amino acid total & $55.37 \pm 0.34^{\mathrm{a}}$ & $54.17 \pm 0.12^{\mathrm{a}}$ \\
\hline
\end{tabular}

Description: All values are mean \pm SD. The same superscript letters across columns indicate no significant different mean $(P>0.05)$ 
Table 7. Proximate composition (\%dry basis \pm SD) of liver of rabbitfish $\mathrm{S}$. guttatus fed two maturation diets

\begin{tabular}{lcc}
\hline \multirow{1}{*}{$\begin{array}{c}\text { Nutrient } \\
\text { (\%) }\end{array}$} & \multicolumn{2}{c}{ Liver } \\
\cline { 2 - 3 } & FM & SLM \\
\hline Lipid & $4.1 \pm 0.4$ & $2.0 \pm 0.3$ \\
Crude protein & $45.1 \pm 2.5$ & $44.9 \pm 0.4$ \\
Fiber & NA & NA \\
Ash & $4.2 \pm 0.1$ & $3.9 \pm 0.4$ \\
\hline
\end{tabular}

let, possibly indicated that certain amino acid level in gonads were more sensitive to be affected by dietary SLM than by dietary FM.

\section{CONCLUSION}

Dietary SLM enhanced GSI of female broodstocks of rabbitfish from $5.6 \%$ to $11.4 \%$ but did not affect the GSI of male broodstock. Total amino acid content significantly improved by dietary LSM from $30.1 \pm 0.18$ to $49.31 \pm 0.08 \%$ in oocyte and from $46.09 \pm 1.19$ to $62.4 \pm 0.11 \%$ in spermatocyte of golden spotted rabbitfish, Sganus guttatus.

\section{ACKNOWLEDGEMENTS}

The authors thank to the Australian Center for International Agricultural Sciences (ACIAR) for funding this research through Project FIS/2007/124 Diversification of smallholder coastal aquaculture in Indonesia

\section{REFERENCES}

AOAC International. (2005). Official Methods of Analysis. $18^{\text {th }}$ edn. Association of Official Analytical Chemists International. Gaithersburg. Maryland. USA. 1141 pp.

Araujo, B., Honji, R., De Mello, P., \& Moreira, R. (2012). The influence of captive breeding on the fatty acid profiles of Salminus hilarii (Characiformes: Characidae) eggs and larvae. Aquaculture International, 20, 1161-1181.

Avila, E.M . \& Juario, J.V. (1987). Yolk and oil globule utilization and developmental morphology of the digestive tract epithelium in larval rabbitfish, Siganus 5guttatus (Bloch). Aquaculture, 65, 319331.

Bariche, M. (2006). Diet of the Lessepsian fishes, Siganus rivulatu and $\mathrm{S}$. luridus (Siganidae) in the eastern Mediterranean: a bibliographic analysis. Cybium, 30, 41-49.
Binh, T.N., Koshio, S., Sakiyama, K., Harakawa, S., Gao, J., Mamauag, R.E., Ishikawa, M., \& Yokoyama, S. (2012). Effects of dietary vitamin $C$ and $E$ and their interactions on reproductive performance, larval quality and tissue vitamin contents in kuruma shrimp, Marsupenaus japonicus Bate. Aquaculture, 334-337, 73-81.

Callan, C.K., Laidley, C.W., Foster, I.P., Liu, K.M., Kling, L.J., \& Place, A.R. (2012). Examination of broodstock diet effects on egg production and egg quality in flame angelfish (Centropygeloriculus). Aquaculture Research, 43, 696-705.

Cerda, J., Carrillo, M., Zanuy, S., Ramos, J., \& de la Higuera, M. (1994). Influence of nutritional composition of diet on seabass, Dicentrarchus labrax L., reproductive performance and egg and larval quality. Aquaculture, 128, 345-361.

Coman, G.J., Arnold, S.J., Barclay, M., \& Smith, D.M. (2011). Effect of arachidonic acid supplementation on reproductive performance of tank-domesticated Penaeus monodon. Aquaculture Nutrition, 17, 141-151.

Duray, M.N. (1998). Biology and culture of siganids. Aquaculture Department, Southeast Asian Fisheries Development Center, Tigbauan, Iloilo, Philippines. 53 pp.

Fernandez-Palacios, H., Izquierdo, M., Robaina, L., Valencia, A., Salhi, M., \& Montero, D. (1997). The effect of dietary protein and lipid from squid and fish meals on egg quality of broodstock for gilthead seabream (Sparus aurata). Aquaculture, 148, 233-246.

Hertrampf, J.W. \& Piedad-Pascual, P. (2000). Handbook on ingredient for aquaculture feeds. Kluwer Academic Publishers, 573 pp.

Hyllner, S.J., Fernandez-Palacios, H., Larsson, D.G.J., \& Haux, C. (1995). Amino acid composition and endocrine control of vitelline envelope proteins in European sea bass (Dicentrarchus labrax) and 
gilthead sebaream (Sparus aurata). Molecular Reproductive Development, 41, 339-347.

Jaikumar, M. (2012). A review on biology and aquaculture potential of rabbitfish in Tamilnadu (Siganus canaliculatus). International Journal of Plant, Animal and Environmental Sciences, 2(2), 57-64.

Kader, M.A., Koshio, S., Ishikawa, M., Yokoyama, S., Bulbul, M., Nuyen, B.T., Gao, J., \& Laining, A. (2012). Can fermented soybean meal and squid by-product blend be used as fishmeal replacements for Japanese flounder (Paralichthys olivaceus)?. Aquaculture Research, 43, 1427-1438.

Koshio, S. (2010). Vitamin requirements of shrimp and prawns. In Alday-Sanz, V. (Ed.). TheShrimp Book. Nottingham, UK: Nottingham University Press: $p$. 491-496.

Laining, A., Lante, S., \& Parenrengi, A. (2015). Gonado somatic index and profile of fillet fatty acid of rabbitfish, Siganus guttatus broodstock fed carotenoid supplemented diets (p. 79-84). In Proceeding of International Conference on Aquaculture Indonesia, Jakarta, 28-31 October 2015.

Laining A., Usman, \& Syah, R. (2017a). Nutritive value of copra cake meal fermented with Rhizopus spp. and its use as protein source for practical diet for rabbitfish (Siganus javus). Journal of Applied Aquaculture, 29(3-4), 307-321.

Laining, A., Trismawanti, I., Kamaruddin, \& Makmur. (2017b). Carotenoid-enriched diet for pre-maturation stage of pond-reared tiger shrimp, Penaeus monodon. Part I. Effect on growth, pigmentation and whole body nutrient content. Indonesian Aquaculture Journal, 12(2), 59-66.

Liang, M., Yu, H., Chang, Q., Chen C., \& Sun, S. (2000). Feeding attraction activities of food attractants for 3 species of fishes. Journal of Fisheries Sciences of China, 7, 60-63.

Mai, K., Li, H., Duan, Q., Xu, W., Zhang, C., Zhang, L., Tan, B., \& Liufu, Z. (2006). Effects of dietary squid viscera meal on growth and cadmium accumulation in tissues of Japanese seabass, Lateolabrax japonicus (Cuvier 1828). Aquculture Research, 37, 1063-1069.

Mejri, S., Tremnlay, R., Vandenberg, G., Moren, M., Khemis, I.B., \& Auder, C. (2017). Differences in nutrient content of eggs and larvae as indicators for improvement of broodstock nutrition in walleye (Sander vitreus). Canadian Journal of Zoology, 95(5), 299-310.

Moran, D., Gara, B., \& Wells, R.M.G. (2007). Energetics and metabolism of yellowtail kingfish (Seriola lalandi) during embryogenesis. Aquaculture, 265, 359-369.
Parazo, M.M. (1990). Effect of dietary protein and energy level on growth, protein utilization and carcass composition of rabbitfish, Siganus guttatus. Aquaculture, 86, 41-49.

Penaflorida, V.D. (1989). An evaluation of indigenous protein sources as potential component in the diet formulation for tiger prawn, Penaeus monodon, using amino acid index (EAAl). Aquaculture, 83, 319-330.

Rachmansyah, Usman, Lante, S., \& Ahmad, T. (2007). Rabbitfish, Siganus guttatus. Breeding and larva rearing trial. Aquaculture Asia, 12(3), 39-40.

Saoud, I.P., Ghanawi, J., \& Lebbos, N. (2008). Effects of stocking density on the survival, growth, size variation and condition index of juvenile rabbitfish Siganus rivulatus. Aquaculture International, 16, 109116.

Tacon, A.G.J., Rausin, N., Kadari, M., \& Cornelis, P. (1990). The food and feeding of marine finfish in floating net cages at the National Seafarming Development Centre, Lampung, Indonesia: rabbitfish, Siganus canaliculatus (Park). Aquaculture and Fisheries Management, 21, 375-390.

Tandler, A., Harel, M., Koven, W.M., \& Kolkovsky, S. (1995). Broodstock and larvae nutrition in gilthead seabream Sparus aurata new findings on its involvement in improving growth, survival and swim bladder inflation. Israel Journal of Aquaculture Bamidgeh, 47, 95-111.

Vassallo-Agius, R., Imaizumi, H., Watanabe, T., Yamazaki, T., Satoh, S., \& Kiron, V. (2001). The influence of astaxanthin supplemented dry pellets on spawning of striped jack. Fisheries Science, 67, 260-270.

Vassallo-Agius, R., Watanabe, T., Imaizumi, H., \& Yamazaki, T. (2002). Spawning performance of yellowtail fed dry pellets containing paprika and squid meal. Fisheries Science, 68, 230-232.

Watanabe, T., Lee, M.J., Mizutani, J., Yamada, T., Satoh, S., Takeuchi, T., Yoshida, N., Kitada, T., \& Arakawa, T. (1991). Effective components in cuttlefish meal and raw krill for the improvement of quality of red sea bream Pagrus major eggs. Nippon Suisan Gakkaishi, 57, 681-694.

Watanabe, T. \& Kiron, V. (1995). Broodstock management and nutritional approaches for quality offsprings in the red seabream. In Bromage, N.R. \& Roberts, R.J. (Eds.). Broodstock management and egg and larval quality. Cambridge: Cambridge University Press, p. 82-93.

Watanabe, T. \& Vasallo-Agius, R. (2003). Broodstock nutrition research on marine finfish in Japan. Aquaculture, 227, 35-61. 